\title{
The Role of Legal Compliance and Good Corporate Governance on Reducing Audit Delay on Publicly Listed Companies in Indonesia
}

\author{
Lailah Fujianti ${ }^{1}$ \\ ${ }^{1}$ Universitas Pancasila, Jakarta, Indonesia \\ Correspondence: Lailah Fujianti, Universitas Pancasila, Jakarta, Indonesia. E-mail: lfuji.feup@gmail.com
}

Received: September 18, 2019

Accepted: December 10, 2019 Online Published: December 15, 2019

doi:10.5430/rwe.v10n3p359

URL: https://doi.org/10.5430/rwe.v10n3p359

\begin{abstract}
Audit Report Lag (ARL) the completion of the audit that the length of time is measured from the date of closing of the financial year until the issuance of the audit report signed by the auditor. Benefits of the financial statements will be reduced if the report is not available on time. This study examines the Good Corporate Governance (GCG) mecanism and eksternal auditor that affect ARL including the board of ditectors, independent board of ditectors, audit committee and the external auditors and regulatory pressures. This study sampled kompas 100 companies in Indonesia Stock Exchange, with a sample of 94 . This study was measured by using a Moderated regression analysis. These results indicate that Partially, the board of directors, independent board of directors have a significant effect on ARL before and after uses moderating variabel legal pressure, and the audit committe, external auditors have not a significant effect on ARL. Regulatory pressures plays a role as a moderator variable in the relationship the ARL with the GCG.
\end{abstract}

Keywords: audit report lag, audit committee, board of directors, external auditor

\section{Introduction}

Information about the financial position, results of operations, changes in capital position and the company's cash flow within a certain time period are presented in the company's financial statements. This information is useful for interested parties as one input in making business decisions when presented on time (Fujianti, 2016). Timeliness of financial statement presentation is an important element for the functioning of the capital market mechanism. Delays in presenting financial statements can result in reduced relevance of financial information in decision making.

Considering the importance of the timeliness of presenting the financial statements of the Capital Market and Financial Institution Supervisory Agency which is now renamed the Financial Services Authority (OJK) issued a regulation regarding the deadline for presenting financial statements and fines for the presumption of annual financial statement presentation. Financial Services Authority Regulation Number 29/Pojk.04/2016 Concerning Annual Reports of Issuers or Public Companies determine the deadline for the presentation of financial statements by companies listed on the Indonesia Stock Exchange at the end of the fourth month after the financial year ends and administration for the late. Even though the deadline for presenting financial statements and fines has been determined, it is proven that there are still many companies that are late in presenting financial statements.

Table 1. Number of late companies presenting financial statements

\begin{tabular}{cc}
\hline Year & Number of Companies \\
\hline 2013 & 52 \\
\hline 2014 & 49 \\
\hline 2015 & 52 \\
\hline 2016 & 18 \\
\hline 2017 & 70
\end{tabular}

The length of time for the presentation of financial statements until the date of issuance of audited financial statements is called Audit Report Lag / ARL (Habib and Bhuiyan 2011; Reheul et al. 2013). ARL has been the object 
of research by many researchers in various countries, both in developed and developing countries. Variables that were examined extensively in relation to ARL were revealed from previous studies, namely audit related variables (Lee and Jahng, 2008) such as audit risk, audit complexity and auditor expertise (Chan et al, 2015), auditor type, auditor change, type of audit opinion (Ahmed and Hossain, 2010). This is because the financial statements presented to the public must have been through an audit process by an external auditor. External auditors need time to complete the audit process so that it will affect ARL.

In addition to the audit variables, the mechanism of Good Corporate Governance (GCG) as a variable that influences ARL is also widely studied in previous studies, because the GCG mechanism includes the ownership structure, the board of commissioners, the board of directors, the audit committee that functions as the supervisor and controller of management actions in making operational decisions company. GCG also facilitates the presentation of financial statements on time (Ilaboya and Christian, 2014). However, the results of the study show a contradiction in the effect of the GCG mechanism on ARL. Azubike and Anggreh (2014) showed the influence of the size of the board of commissioners on ARL while Nor et al. (2010) shows the opposite has no effect. Apadore and Noor (2013) documented that the independent board of commissioners had a significant effect on ARL while Li et al. (2014) shows the opposite results. Voku and Cular (2014) show that independent audit committees have a significant effect on ARL while Aljaaidi et al (2015) show the opposite.

Previous research has not yet examined the legal compliance pressure associated with ARL. This legal compliance pressure forces a person or organization to comply, because if not, the risk of witnesses must be borne by the organization or company. Lord and Dezoort (2001) state that an auditor who is subject to compliance with both legal / regulatory and social compliance will affect the audit quality. This legal compliance pressure is predicted to play an important role on ARL, because corporate GCG is to include people who are rational. Rational people will certainly not avoid risk or witness. The law enforcement stress variable is a variable worth studying in the relationship of GCG to ARL. For this reason, this study will review the effect of audit and GCG variables on ARL and examine the ability to moderate the legal compliance pressure variables in the relationship of GCG variables to ARL. This variable, the legal obedience pressure, hereinafter referred to as legal obedience, is a new variable added in this study.

\section{Literature Review and Hypothesis Development}

\subsection{Board of Commissioners and Audit Report Lag}

One of the weaknesses of BoC's large size is communication and coordination problems (Nor et al., 2010). This makes the board of commissioners less capable and less efficient at monitoring company operations compared to the small size of the board of commissioners (Dimitropoulos \& Asteriou, 2010). Mak and Li (2001) argue that the large size of the BoC is less able to participate and is not organized so that it cannot reach agreement. Xie et al. (2003) also argue that the small size of the board of commissioners is not burdened with bureaucratic problems, so that they are better able to provide better financial supervision reports.

\section{H1: The Board of Commissioners influences the audit report lag.}

\subsection{Independent Board of Commissioners and Audit Report Lag}

Independent Board of Commissioners $(\mathrm{BoC})$ is a board of commissioners from outside the company. This council has proven to be important and has been recognized and even regulated in capital market regulations regarding the necessity of companies to have BoC. GCG mechanisms in many countries pay special attention to having a reasonable proportion of $\mathrm{BoC}$ in the company. $\mathrm{BoC}$ is an important element in the GCG mechanism and its presence on the board of commissioners is a recommendation from GCG practitioners (Zattoni \& Cuomo, 2010). Regulations from various countries require that an independent commissioner develop the duties and responsibilities to carry out effective supervision (Lazar et al., 2014) on the behavior of directors. BoC which effectively monitors the behavior of directors in the interests of minorities (El Masry, 2008).

\section{H2: The Independent Board of Commissioners has a negative effect on audit report lag.}

\subsection{Independent Audit Committee and Audit Lag Report}

Independent Audit Committee (IAC) is an important part of the GCG structure specifically related to the quality and issuance of financial statements (Ika and Ghazali, 2012) and is an important monitor in the financial reporting process. Regulators and investors call on audit committees to be independent from management to be able to carry out effective monitoring, so as to suppress opportunistic behavior of management, and ensure the presentation of quality financial statements (Agoglia, et al. 2011). 
This audit committee usually has a majority of members of the executive and is expected to look at the company's affairs in a separate and impartial manner. The quality and credibility of financial reporting can decrease when the audit committee has low independence or is not independent (Habbash, 2010). One of the objectives of the audit committee is to provide an objective review of financial information (Emeh, 2013) and Archambeault et al (2008) show that the independence of the audit committee reduces earnings management and the possibility of presenting financial reporting fraud. Likewise, Choi et al. (2004) found when audit committee members owned shares in the company, they were less effective in reducing earnings management. Thus, the independence of the audit committee is a key factor in increasing its role in preventing mis-statements in the financial statements.

\section{H3: The independent audit committee has a negative effect on audit report lag.}

\subsection{External Auditors and Audit Lag Report}

Financial statements that are presented to the public must go through an audit process by the External Auditor (EA) to obtain the integrity and legitimacy of the accuracy of the financial statements. The audit process takes time so that it can influence ARL. Afify (2009) states that large audit companies have a strong motivation to complete audit work in a timely manner, in order to preserve their reputation and name. The reputation of the Public Accounting Firm (PAF) is a signal that the PAF is conducting an audit process well so that it can maintain public trust. Large PAFs are predicted to complete the audit process faster than smaller PAFs, because they have more qualified audit staff. The auditor's expertise has an impact on the efficiency and effectiveness of the audit process (Blankley et al. 2014). The auditor's broader knowledge about the client's line of business or the specifications of the type of industry, enables the auditor to identify and overcome risks in the audit process (Blankley et al., 2015). Habib (2015) states that large PAFs produce shorter ARL compared to small and medium auditor PAFs. Lee et al. (2009); Dao, and Pham (2014) prove there is an influence of external audit on ARL.

\section{H4: The external auditor influences the audit report lag.}

\subsection{Legal Compliance and Audit Report Lag}

The timeliness of the presentation of financial statements received attention from regulators (Krishnan and Yang 2009; Abbott et al. 2012; Bronson et al. 2011). This attention is mainly aimed at the deadline for presentation of the report. Securities and Exchange Commission (SEC) regulators in several countries have established regulations regarding deadlines for the presentation of financial statements in order to reduce delays in presenting financial statements by many public companies (Lambert et al. 2013). The Indonesia Stock Exchange has also set rules regarding the deadline for the presentation of financial statements for listed companies, which is March 31 the following year after the financial statement date ends. The deadline for the presentation of financial statements is a pressure for companies to reduce ARL, because companies that do not comply with these regulations will be subject to witnesses in the form of fines of $\mathrm{Rp} 150$ million. Therefore this regulation is a pressure for companies to comply with these regulations. The pressure to obey the rules in this study is termed legal compliance.

H5: Legal compliance has a negative effect on audit report lag.

H6: The higher the size of the board of commissioners and the legal compliance affect the shorter audit report lag.

H7: The higher the size of the independent board of commissioners and the legal compliance affect the shorter audit report lag.

H8: The higher the size of the independent audit committee and legal compliance affect the shorter audit report lag.

\section{Research Methods}

Determination of the sample based on purposive sampling method, namely companies listed in the compass group 100 in 2016. Based on the sample selection criteria obtained 95 companies and 5 companies were excluded from observation because they did not have complete data.

The variables in this study were measured based on previous research, except for the legal pressure variable measured by rank. The dependent variable of Audit Report Lag (ARL) is defined as number of days from the closing date of the book until the date the audit report is signed with the measurement scale of ratio. The independent variable of Board of Commissioners is defined as the ratio of the number of members of the board of commissioners to the board of directors with the measurement by using ratio scale. The independent variable of independent Board of Commissioners (BOC) is defined as the ratio of the number of independent commissioners to the members of the board of commissioners with the measurement by using ratio scale. The independent variable of independent 
Audit Committee (IAC) is defined as the ratio of the number of independent audit committee members to the audit committee members with the measurement by using ratio scale. External Auditor (AE) is measured with the measurement using nominal scale that Big Four accounting firms $=1$ and Non big four $=0$.

As moderator, legal compliance is measured with ratio scale that timely submit the financial statements to IDX $=2$, not timely submit the financial statements to IDX $=1$, and not submit financial statements to IDX $=0$. As control variables, Total Assets (TA) is measured with log total assets using ratio scale and Profitability (PROFIT) is measured with Net profit margin using ratio scale.

For legal pressure, rank 2 is given to companies that timely present financial statements in the previous year, 1 is given to companies that are late in presenting and 0 for companies that do not present. The measurement based on this ranking is based on the logic that the right time will be better than the wrong time and the wrong time is better than not presenting a financial report. This study also includes control variables, namely Total Assets (TA) as measured by log total and Profitability (PROFIT) as measured by net profit margin.

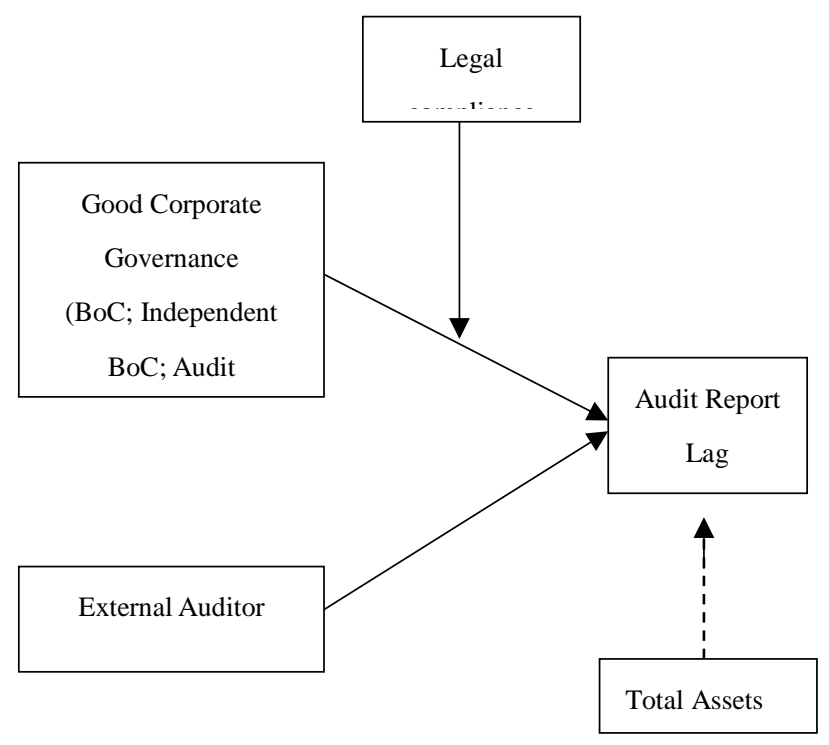

Figure 1. Research model

\section{Results}

The object of research is companies listed in compass 100 in 2013 . The total population is 100 companies minus 5 companies that do not have complete data and 1 data outlier, so the number of study samples is 94 .

Table 2. Descriptive statistics

\begin{tabular}{lcccc}
\hline & Min. & Max. & Mean & Std. Dev. \\
\hline ARL & 16.000 & 90.000 & 67.362 & $17,4950,363$ \\
\hline BoC & 0.364 & 2.167 & 0.915 & 0.363 \\
\hline IBoC & 0.167 & 0.800 & 0.436 & 0.118 \\
\hline IAC & 0.000 & 1.000 & 0.676 & 0.197 \\
\hline EA & 0.000 & 1.000 & 0.660 & 0.476 \\
\hline LC & 1.000 & 2.000 & 1.734 & 0.444 \\
\hline TA & 5.209 & 8.865 & 7.201 & 0.656 \\
\hline PROFIT & -33.240 & 62,900 & 12,579 & 17.010
\end{tabular}

ARL: Audit report lag; BoC: Board of Commissioners; IBoC: Independent Board of Commissioners; IAC: Independent Audit Committee; EA: external auditor; :LC: legal compliance; TA: total assets; Profit: Profitability 
The ARL variable has a minimum value of 16 days, a maximum of 90 days, an average of 67,362 days and a standard deviation of 17,495 . The DK variable with a minimum value is 0.364 , a maximum of 2.167 , an average of 0.915 and a standard deviation of 0.363 . The BOC variable value of minimum value is 0.167 , maximum of 0.800 , average of 0.436 and standard deviation of 0.118 . IAC minimum value is 0.00 , meaning that there are companies that do not have an independent audit committee, a maximum of 1.000 , meaning that the company has a maximum of one audit committee. The AE variable has a minimum value of 0.00 and a maximum of 0.100 . A value of 0.00 means being audited by non big four and 1 being audited by big four. There are 22 companies audited by non big four companies and big for 72 . The $\mathrm{KH}$ variable with a minimum value is 1.00 . A value of 1.00 means that the company is not timely in presenting financial statements. There were 25 companies which did not meet on time. The KH variable has a maximum value of 2.00. A value of 2.00 means that on time the presentation of the financial statements of the previous year totaling 69 companies. The TA variable is measured by natural logarithm of total assets while the PROFIT variable is measured by Net Profit Margin.

Table 3. Pearson Correlation

\begin{tabular}{lcccccccc}
\hline & ARL & BoC & IBoC & IAC & EA & LC & TA & PROFIT \\
\hline ARL & 1 & & & & & & & \\
\hline BoC & .019 & 1 & & & & & & \\
\hline IBoC & -.041 & -.052 & 1 & & & & & \\
\hline IAC & .016 &, 197 & -.020 & 1 & & & & \\
\hline EA & -.145 & $-.209^{*}$ & -.018 & .084 & 1 & & & \\
\hline LC & $-.237^{*}$ & -.067 &, 158 & -.117 &, 126 & 1 & & \\
\hline TA & $-.431^{* *}$ & -.047 & .097 & .006 &, $260^{*}$ & .081 & 1 & \\
\hline PROFIT & $-.247^{* *}$ & -.084 &, 193 & -.117 & -.077 & .090 &, 196 & 1 \\
\hline
\end{tabular}

Note: ARL: Audit report lag; BoC: Board of Commissioners; IBoC: Independent Board of Commissioners; IAC: Independent Audit Committee; EA: external auditor; :LC: legal compliance; TA: total assets; Profit: Profitability

*. Correlation is significant at the 0.05 level (2-tailed); **. Correlation is significant at the 0.01 level (2-tailed)

Table 2 shows the correlation matrix of each variable. BoC was not positively related to ARL $(0.019, p>0.05)$, while independent BoC had no significant negative correlation with ARL $(-0.041, \mathrm{p}>0.05)$. IAC was positively not significantly related to ARL (0.016, $\mathrm{p}>0.05)$. External auditors are negatively associated with insignificant ARL $(-0.145, \mathrm{p}>0.05)$. KH was significantly negatively related to ARL $(-0.237, \mathrm{p}<0.01)$. Two control variables namely TA were significantly negatively related to ARL $(0.431, \mathrm{p}<0.01)$ and significant negative profit with ARL $(0.274, \mathrm{p}$ $<0.01)$.

Table 4. Regression Test Results

\begin{tabular}{|c|c|c|c|c|c|c|}
\hline \multirow[t]{2}{*}{ Variable } & \multirow[t]{2}{*}{ Expected Sign } & \multicolumn{2}{|c|}{$\begin{array}{l}\text { Unstandardized } \\
\text { Coefficients }\end{array}$} & \multirow{2}{*}{$\begin{array}{c}\text { Standardized } \\
\text { Coefficients } \\
\text { Beta }\end{array}$} & \multirow[t]{2}{*}{$\mathrm{t}$} & \multirow[t]{2}{*}{ Sig. } \\
\hline & & B & Std. Error & & & \\
\hline (Constant) & $?$ & 183.264 & 22.699 & & 8.074 & $.000 * *$ \\
\hline $\mathrm{BoC}$ & $?$ & 23.663 & 8.102 & 492 & 2.921 & $.004 * *$ \\
\hline IBoC & - & -188.989 & 47.738 & $-1,277$ & -3.959 & $.000^{* *}$ \\
\hline IAC & - & 30.011 & 26.060 & 339 & 1.152 & .253 \\
\hline EA & $?$ & -3.042 & 3.301 & -.083 & -.921 & .359 \\
\hline $\mathrm{LC}$ & - & -21.508 & 7.761 & -.546 & -2.771 & $.007 * *$ \\
\hline TA & - & -9.818 & 2.341 & -.368 & -4.194 & $.000^{* *}$ \\
\hline PROFIT & - & -.294 & .093 & -.286 & -3.170 & $.002 * *$ \\
\hline $\mathrm{LC} * \mathrm{BoC}$ & $?$ & -14.214 & 4.304 & -.625 & -3.303 & $.001 * *$ \\
\hline LC*IBoC & $?$ & 106.238 & 25.256 & 1.840 & 4.207 & $.000 * *$ \\
\hline
\end{tabular}




\begin{tabular}{lcccccc}
\hline LC*IAC & $?$ & -18.392 & 14.211 & -.454 & -1.294 & .199 \\
\hline Adjusted R & 0.372 & & & & & \\
\hline F Statistics & 0 & & & & & \\
\hline$*$ significant at the 0.05 level (2-tailed); $* *$ significant at the 0.01 level (2-tailed). & &
\end{tabular}

Table 4 shows the results of the regression test for hypothesis testing. The results of this test have fulfilled the classic assumption test and model fit test with F statistic $(\mathrm{p}<0.01)$ with adjusted R2 of $37.2 \%$. The test results showed that variables $\mathrm{BoC}$, IBoC, LC, TA, PROFIT, $\mathrm{LC} * \mathrm{BoC}$, and $\mathrm{LC} * \mathrm{BoC}$ had a significant effect $(\mathrm{p}<0.01)$ with ARL, while IAC, EA and LC*IAC were not significant.

\section{Conclusions}

The existence of a deadline for presenting financial statements on the IDX is a determining factor for GCG in reducing audit report delay in Indonesia. This proves that the existence of a board of commissioners, an independent board of commissioners, an audit committee does not necessarily present a timely financial report, but must be suppressed first through applicable regulations or laws. For this reason, Bapepan is right to provide witnesses to companies listed on the Indonesia Stock Exchange if it is too late to present financial statements in the form of fines, having to pay Rp. 150.000.000. previous. In this study there are still 25 companies that present financial statements exceeding the specified time limit, for that in the future it may be more stringent sanctions in the form of deletion from listed companies in order to reduce or minimize companies that do not meet the accuracy of financial statement presentation and if this fulfilled then ARL can be reduced or shortened.

\section{References}

Abbott, L. J., Parker, S., \& Peters, G. F. (2012). Internal audit assistance and external audit timeliness. Auditing: A Journal of Practice \& Theory, 31(4), 3-20.

Afify, H. A. E. (2009). Determinants of audit report lag: Does implementing corporate governance have any impact? Empirical evidence from Egypt. Journal of Applied Accounting Research, 10(1), 56-86.

Agoglia, C. P., Doupnik, T. S., \& Tsakumis, G. T. (2011). Principles-based versus rules-based accounting standards: The influence of standard precision and audit committee strength on financial reporting decisions. The Accounting Review, 86(3), 747-767.

Ahmed, A. A. A., \& Hossain, M. S. (2010). Audit report lag: A study of the Bangladeshi listed companies. ASA University Review, 4(2), 49-56.

Aljaaidi, K. S., Bagulaidah, G. S., Ismail, N. A., \& Fadzil, F. H. (2015). An Empirical Invistigation of Determinants Associated with Audit Report Lag in Jordan. Jordan Journal of Business Administration, 11(4).

Apadore, K., \& Noor, M. M. (2013). Determinants of Audit Report Lag and Corporate Governance in Malaysia. International Journal of Business and Management, 8(15), 151-163.

Archambeault, D. S., DeZoort, F. T., \& Hermanson, D. R. (2008). Audit committee incentive compensation and accounting restatements. Contemporary Accounting Research, 25(4), 965-992.

Azubike, J. U. B., \& Aggreh, M. (2014). Corporate governance and audit delay in Nigerian quoted companies. European Journal of Accounting Auditing and Finance Research, 2(10), 22-33.

Blankley, A. I., Hurtt, D. N., \& MacGregor, J. E. (2014). The relationship between audit report lags and future restatements. Auditing: A Journal of Practice \& Theory, 33(2), 27-57.

Blankley, A. I., Hurtt, D. N., \& MacGregor, J. E. (2015). Are lengthy audit report lags a warning signal?. Current Issues in Auditing, 9(2), P19-P28.

Bronson, S. N., Hogan, C. E., Johnson, M. F., \& Ramesh, K. (2011). The unintended consequences of PCAOB auditing Standard Nos. 2 and 3 on the reliability of preliminary earnings releases. Journal of Accounting and Economics, 51(1-2), 95-114.

Chan, K. H., Luo, V. W., \& Mo, P. L. (2016). Determinants and implications of long audit reporting lags: evidence from China. Accounting and Business Research, 46(2), 145-166.

Choi, J. H., Jeon, K. A., \& Park, J. I. (2004). The role of audit committees in decreasing earnings management: Korean evidence. International Journal of Accounting, Auditing and Performance Evaluation, 1(1), 37-60. 
Dao, M., \& Pham, T. (2014). Audit tenure, auditor specialization and audit report lag. Managerial Auditing Journal, 29(6), 490-512.

Dimitropoulos, P. E., \& Asteriou, D. (2010). The effect of board composition on the informativeness and quality of annual earnings: Empirical evidence from Greece. Research in International Business and Finance, 24(2), 190-205.

Emeh, Y., \& Appah, E. (2013). Audit committee and timeliness of financial reports: Empirical evidence from Nigeria. Journal of Economics and sustainable Development, 4(20), 14-25.

Ezat, A., \& El-Masry, A. (2008). The impact of corporate governance on the timeliness of corporate internet reporting by Egyptian listed companies. Managerial Finance, 34(12), 848-867.

Fujianti, L. (2016). Analysis Market Reaction on Timeliness Reporting: Study on Indonesia Stock Exchange. International Journal of Business Management and Invention, 5(3), 1-10.

Habbash, M. (2010). The effectiveness of corporate governance and external audit on constraining earnings management practice in the UK. Doctoral dissertation, Durham University.

Habib, A. (2015). The New C hinese Accounting Standards and Audit Report Lag. International Journal of Auditing, 19(1), 1-14.

Habib, A., \& Bhuiyan, M. B. U. (2011). Audit firm industry specialization and the audit report lag. Journal of International Accounting, Auditing and Taxation, 20(1), 32-44.

Ika, S. R, \& Mohd Ghazali, N. A. (2012). Audit committee effectiveness and timeliness of reporting: Indonesian evidence. Managerial Auditing Journal, 27(4), 403-424.

Ilaboya, O. J., \& Christian, I. (2014). Corporate governance and audit report lag in Nigeria. International Journal of Humanities and Social Science, 4(13), 172-180.

Krishnan, J., \& Yang, J. S. (2009). Recent trends in audit report and earnings announcement lags. Accounting Horizons, 23(3), 265-288.

Lambert, T. A., Jones, K. L., \& Brazel, J. F. (2013). Unintended Consequences of Accelerated Filings: Are Mandatory Reductions in Audit Quality Associated with Reductions in Earnings Quality? Working paper, Lehigh University.

Lazar, C., Metzner, Y., Rapp, M. S., \& Wolff, M. (2014). Remuneration of non-executive directors in German listed firms: An empirical analysis from a practitioners' perspective. Accounting, Economics and Law, 4(1), 1-16.

Li, Y., Zhang, D., \& Wang, X. (2014). The influence of corporation governance structure on internal control audit report lag: evidence from China. Accounting \& Taxation, 6(2), 101-115.

Lord, A. T., \& DeZoort, F. T. (2001). The impact of commitment and moral reasoning on auditors' responses to social influence pressure. Accounting, Organizations and Society, 26(3), 215-235.

Mak, Y. T., \& Li, Y. (2001). Determinants of corporate ownership and board structure: evidence from Singapore. Journal of Corporate Finance, 7(3), 235-256.

Naimi, M., Nor, M., Rohami, S., \& Wan-Hussin, W. N. (2010). Corporate governance and audit report lag in Malaysia. Corporate Governance and Audit Report Lag in Malaysia (October 20, 2010). Asian Academy of Management Journal of Accounting and Finance, 6(2).

Pham, T., Dao, M., \& Brown, V. L. (2014). Investment opportunities and audit report lags: Initial evidence. Accounting and Finance Research, 3(4), 45-57.

Pham, T., Dao, M., \& Brown, V. L. (2014). Investment opportunities and audit report lags: Initial evidence. Accounting and Finance Research, 3(4), 45-57.

Vuko, T., \& Čular, M. (2014). Finding determinants of audit delay by pooled OLS regression analysis. Croatian Operational Research Review, 5(1), 81-91.

Xie, B., Davidson III, W. N., \& DaDalt, P. J. (2003). Earnings management and corporate governance: the role of the board and the audit committee. Journal of Corporate Finance, 9(3), 295-316.

Zattoni, A., \& Cuomo, F. (2010). How independent, competent and incentivized should non-executive directors be? An empirical investigation of good governance codes. British Journal of Management, 21(1), 63-79. 